Kansas State University Libraries

New Prairie Press

\title{
Women Professor's Ways of Working in Academia
}

\author{
Rachel Wlodarsky \\ r.wlodarsky@csuohio.edu \\ Catherine Hansman \\ Cleveland State University, c.hansman@csuohio.edu
}

Follow this and additional works at: https://newprairiepress.org/aerc

Part of the Adult and Continuing Education Administration Commons

\section{(c) (i) (9)}

This work is licensed under a Creative Commons Attribution-Noncommercial 4.0 License

\section{Recommended Citation}

Wlodarsky, Rachel and Hansman, Catherine (2019). "Women Professor's Ways of Working in Academia," Adult Education Research Conference. https://newprairiepress.org/aerc/2019/roundtables/3

This Event is brought to you for free and open access by the Conferences at New Prairie Press. It has been accepted for inclusion in Adult Education Research Conference by an authorized administrator of New Prairie Press. For more information, please contact cads@k-state.edu. 


\title{
Women Professor's Ways of Working in Academia
}

\author{
Rachel Wlodarsky and Catherine Hansman \\ Cleveland State University
}

\begin{abstract}
We addressed which women's development theories might explain women professors' academic identity, unique pressures faced by women faculty members, and how these issues impact work-life balance.
\end{abstract}

Keywords: Women's Identity, Career Stages, Ethic of Care and Mentoring

As seasoned faculty members can attest, the road to gaining promotion and tenure in institutions of higher education can be difficult and multifaceted. Faculty members who are also parents face many challenges, among them maintaining a healthy work-life balance. Work-life balance issues are complex, and although this need for balance is not gendered (i.e. males who have sole custody of their child(ren), gay couples with children), we have chosen to focus on the challenges women faculty members face, particularly balancing their work and personal lives. We pose various questions that assist us in exploring these issues. For example, what developmental theories frame and explain women professors' academic identity? What are the unique pressures faced by women faculty members as they work towards tenure and promotion? What impact does the continuing expectations for research, service and teaching have on women professors who strive to balance their personal lives with career obligations? And finally, how can higher education institutions better support women professors?

We are two women faculty members who are at different stages of our academic careers and have experienced personally the struggle to balance our work and personal lives. To explore ways to manage our roles as faculty members with our personal lives, we examined some of the foundational developmental theories, Gilligan's A Different Voice (1982), Belenky, Clinchy, Goldberger and Tarule's Women's Ways of Knowing (1986), Josselson's Finding Herself (1987). We also surveyed current literature; for instance, Allan (2012) discusses the "chilly climate in academe that reinscribes traditional gender norms discouraging to all women in our storied halls" (p. 67), norms that are "often nuanced, unconsciously applied, and demoralizing to women students and faculty” (Fox, 2017, p. 16). Massé (2017) argues that although affirmative action, family medical leave, sexual harassment, LGBTQ, and Title IX polices have encouraged the development of women friendly campuses, and despite the fact that the percentage of women earning doctorates is higher than males, women faculty members are still not equally present in academe. In Massés' view, this is the result of "often unexamined gender-normative institutionalization of professional life stages" (p. xv) - or the life stages of academic women that do not necessarily neatly line up with the stages described in developmental theories.

Massé and Bauer-Maglin's (2017) edited book examines the lives of a variety of women in academe and we examine their experiences through the lenses of gender as well as personal and professional life stages. The academic women's stories are organized in stages that do not necessarily reflect women's actual ages, but rather the stages of their careers: Graduate School, Early Career (including tenure), Midcareer (including Post-Tenure), and Late Career and Retirement. We explored the career stages frequently experienced by women faculty members throughout their academic careers, regardless of women's actual ages, using the general categories/stages proposed by Massé and Bauer-Maglin. 
Our exploration of women faculty members' identities, and personal and professional development has raised more questions than answers. The current literature on stages of women's careers in academia paints a picture of working in conditions that may be led by means of masculinity and ethic of justice (Gilligan, 1982; Wright et al., 2017), a constant battle between personal and professional life-one in which women professors feel that no one wins, face continuing financial struggles, experience lack of support or mentorship, have little sense of accomplishment with the continued expectation to do more, feel they may be viewed as inept, and finally, have shuttered hopes of retirement. Are the struggles women faculty members have a result of being silenced and lacking identity, and/or because higher education values and operates under a masculine ethic of justice, not a combination of justice and care?

Our literature review explored the needs of women faculty members and identified different strategies to improve work life balance and assist them to succeed in academe. Although we have offered some insight and strategies through a variety of developmental and career stage lenses, further research concerning women faculty members is necessary, particularly regarding enacting policies to support their development and progression in academe. Future research should explore the ethic of care from an operational perspective to identify how best to integrate it into the culture of universities. It would also be beneficial to give voice to women professors who have experienced a culture of ethic of care within their professional lives to determine their accomplishments and satisfaction with their institutions. In addition, a thorough examination of the literature on organic mentoring, along with identifying situations in which organic mentoring is actively part of the university culture, would be helpful. Finally, comparing the success in terms of work life balance of women faculty members who have participated in formal mentoring programs versus those women faculty members who have not would also add value to our understanding of women professors' needs within the context of higher education.

\section{References}

Allan, E. J. (2012). Special issue: Women's status in higher education - equity matters. ASHE Higher Education Report 37(1), 1-163.

Belenky, M. F., Clinchy, B. M, Goldberger, N. R., \& Tarule, J. M. (1986). Women's ways of knowing: The development of self, voice, and mind. New York, NY: Basic Books, Inc.

Fox, N. S. (2017). Discourse of aspiration: A community of nontraditional students. In M.A. Massé \& N. Bauer-Maglin (Eds.), Staging women's lives in academia: Gendered life stages in language and literature workplaces (pp. 15-27). Albany, NY: SUNY Press.

Gilligan, C. (1982). In a different voice: Psychological theory and women's development. Cambridge, MA: Harvard University Press.

Josselson, R. (1987). Finding herself: Pathways to identity development in women. San Francisco, CA: Jossey-Bass.

Massé, M. A. (2017). Introduction. In M.A. Massé \& N. Bauer-Maglin (Eds.), Staging women's lives in academia: Gendered life stages in language and literature workplaces (pp. xiiixxviii). Albany, NY: SUNY Press.

Massé, M. A., \& Bauer-Maglin, N. (Eds.) (2017). Staging women's lives in academia: Gendered life Stages in language and literature workplaces. Albany, NY: SUNY Press.

Wright, H. R., Cooper, L., \& Luff, P. (2017). Women's ways of working: Circumventing the masculine structures operating within and upon the University. Women's Studies

International Forum, 61, 123-131. 